\title{
A simple non-destructive method for estimating aboveground biomass of emergent aquatic macrophytes
}

Um método não destrutivo simples para estimativa de biomassa aérea de macrófitas aquáticas emergentes

\section{Laís Samira Correia Nunes ${ }^{1 *}$ and Antonio Fernando Monteiro Camargo ${ }^{2}$}

${ }^{1}$ Programa de Pós-graduação em Ciências Biológicas (Biologia Vegetal), Departamento de Ecologia, Instituto de Biociências, Universidade Estadual Paulista - UNESP, Avenida 24A, 1515, CEP 13506-900, Rio Claro, SP, Brazil

${ }^{2}$ Departamento de Ecologia, Instituto de Biociências, Universidade Estadual Paulista - UNESP, Avenida 24A, 1515, CEP 13506-900, Rio Claro, SP, Brazil

*e-mail: laiscorreianunes@gmail.com

Cite as: Nunes, L.S.C. and Camargo, A.F.M. A simple non-destructive method for estimating aboveground biomass of emergent aquatic macrophytes. Acta Limnologica Brasiliensia, 2017, vol. 29 , e2.

Abstract: Aim: Non-destructive methods for estimating aquatic macrophytes biomass may be employed by using indirect measurements, especially in experimental studies, thus enabling the conservation of plant samples. It is possible to estimate macrophyte biomass by developing mathematical equations that relate the plants' dry mass to their morphological variables. The aim of this study was to evaluate the relationship between different morphological variables and biomass in order to determine which variable is easier to be obtained for the emergent aquatic macrophytes Crinum americanum and Spartina alterniflora. Methods: We obtained the aboveground area and height of individuals of both species, with different sizes and distinct developmental stages. The samples were collected in the Itanhaém River Estuary (SP, Brazil). The plants were dried in a laboratory oven and weighed so as to obtain their dry mass. Simple linear regression analyses were applied to the morphological variables and the individual dry mass to obtain equations. Results: For the both species, the relationship between area and biomass, and the relationship between individual height and biomass presented significant coefficients of determination $(\mathrm{p}<0.0001)$. For the elaboration of models involving the individual height, we used only one morphological measure for each individual, whereas for models involving the individual area it was necessary to obtain more than one hundred morphological measurements per individual. Conclusions: The morphological variables chosen are good attributes for estimating the aboveground biomass of $C$. americanum and S. alterniflora. Considering the models' adjustment and the consumed time to obtain the measurements, we conclude that the individual height measurement is better for biomass estimation for both species.

Keywords: dry mass; plant traits; morphological variables; Crinum americanum; Spartina alterniflora.

Resumo: Objetivo: Métodos não destrutivos para avaliação da biomassa de macrófitas aquáticas podem ser empregados usando-se medidas indiretas, especialmente em estudos experimentais, permitindo a conservação das amostras vegetais. Pode-se estimar a biomassa vegetal através da elaboração de equaçóes matemáticas que relacionem a massa seca com as variáveis morfológicas dos vegetais. $\mathrm{O}$ objetivo deste estudo foi avaliar a relaçáo entre diferentes variáveis morfológicas e biomassa para determinar qual variável é mais fácil de ser obtida para as macrófitas aquáticas 
emergentes Crinum americanum e Spartina alterniflora. Métodos: Nós obtivemos a área da fração emergente dos indivíduos e a altura dos indivíduos de ambas as espécies, de diferentes tamanhos e estádios de desenvolvimento, coletadas no estuário do rio Itanhaém (SP, Brazil). As plantas foram secas em estufa e pesadas para obtenção de massa seca. Análises de regressão linear simples foram aplicadas entre as variáveis morfológicas e a massa seca dos indivíduos para a obtenção das equaçóes. Resultados: Para as duas espécies, tanto a relação área e biomassa como a relação altura do indivíduo e biomassa apresentaram coeficientes de determinação significativos $(\mathrm{p}<0,0001)$. Para a elaboração dos modelos envolvendo a altura dos indivíduos utilizamos somente uma medida morfológica para cada indivíduo, enquanto que para os modelos envolvendo a área do indivíduo foi necessária a obtenção de mais de cem medidas morfológicas por indivíduo. Conclusáo: As variáveis morfológicas escolhidas são bons atributos para a estimativa da biomassa da fraçáo emergente de C. americanum e S. alterniflora. Considerando o ajuste dos modelos e o tempo necessário para a obtençáo das medidas, nós concluímos que a medida da altura dos indivíduos é mais adequada para a estimativa da biomassa para ambas as espécies.

Palavras-chave: massa seca; atributos vegetais; medidas morfológicas; Crinum americanum; Spartina alterniflora.

To estimate the abundance of aquatic macrophytes in studies of population and community dynamics is essential (Chambers \& Prepas, 1990). Biomass quantification enables the realization of studies on the ecosystems and the functioning of aquatic plants (Lauck \& Benscoter, 2015), although other metrics, such as cover area, relative abundance scales, and primary productivity can also be used to quantify aquatic plants (Thomaz \& Esteves, 2011).

Destructive methods for assessing macrophyte biomass involve cutting and collecting plants, which generate undesirable consequences for natural environments and difficulties in experimental studies since they limit the number and frequency of samplings (Dai \& Wiegert, 1996; Thomaz et al., 2004; Lauck \& Benscoter, 2015). To reduce the negative effects of destructive methods, it is possible to estimate biomass or macrophyte abundance through indirect measurements, allowing for wider sampling and environmental conservation in studies that require less impact (Gouraud et al., 2008; Silva et al., 2010). Remote sensing-based techniques are being developed as a non-destructive method to estimate macrophyte abundance and to map its large-scale spatial distribution in the field (Long et al., 1994; Byrd et al., 2014; Kim et al., 2016), however, this technology cannot be employed in small-scale and experimental studies. In this case, scanner and laser equipment coupled to digital cameras have been used to scan plant leaves to obtain the leaf area and biomass estimation (Golzarian et al., 2011). Nonetheless, this technique involves high operational costs, imported equipment, and expensive instruments (Rios et al., 2014).
Due to the diversity of biological forms of aquatic macrophytes, the non-destructive biomass estimation does not follow a standard method (Thomaz \& Esteves, 2011). However, as a consistent and low-cost alternative it can estimate biomass by developing mathematical equations that relate dry mass to plant morphological variables (Dai \& Wiegert, 1996; Golzarian et al., 2011). Length, width, leaf area, and the number of leaves are among the morphological variables that may be used since the relationship between morphological variables and biomass is species-specific (Armstrong et al., 2003). This methodology allows for continuous monitoring of biomass changes in experiments, the obtainment of detailed data from plant parts or their overall structure, and the optimization of working time when only simple estimates are necessary. However, it may present a disadvantage when the choosing and collecting of numerous plant attributes are needed to achieve significant biomass relationship (Dai \& Wiegert, 1996).

The aim of this study was to evaluate the relationship between different morphological variables and biomass to determine which variable is easiest to obtain for two species of emergent macrophytes that abound in estuaries in southeastern Brazil.

Crinum americanum L. (Amaryllidaceae) and Spartina alterniflora Loisel. (Poaceae) are emergent macrophyte species that abound in estuarine regions in the state of São Paulo. They occur in abundance in the Itanhaém River Estuary (São Paulo, Brazil) and are distributed forming a gradient with $S$. alterniflora in the estuarine lower portion and $C$. americanum in the upper portion. To understand the causes of such distribution we have performed growth experiments with both 
species in the laboratory. To evaluate growth we used a non-destructive method of biomass evaluation. To elaborate the biomass evaluation method, a sample of 70 individuals of each species, in different sizes and development stages, were collected in the Itanhaém River Estuary.

Most aquatic macrophyte species, especially the emergent ones, present clonal development, making the individuals' identification difficult (Thomaz $\&$ Esteves, 2011). Although C. americanum and $S$. alterniflora are rhizomatous species, the growth form of their shoots and roots enables the identification of individuals, because the leaves of C. americanum are distributed in rosettes (Figure 1) and S. alterniflora forms stems (Figure 2). Thus, we assessed morphological measurements of individuals to relate them to their biomass.

The morphological measurements of the aboveground fraction were: leaf area and height of an individual (height of the largest leaf for C. americanum and culm height for $S$. alterniflora), considering only the green leaves $(50 \%$ or more of chlorophyllated leaf) and disregarding the senescent leaves (less than $50 \%$ of chlorophyllated leaf) and the dead leaves ( $100 \%$ of non-chlorophyllated leaf).

To calculate the aboveground area of C. americanum we considered that its leaves have a rectangular base and a triangular apex, so we obtained the rectangle's height and width measurements and the triangle's height. Using

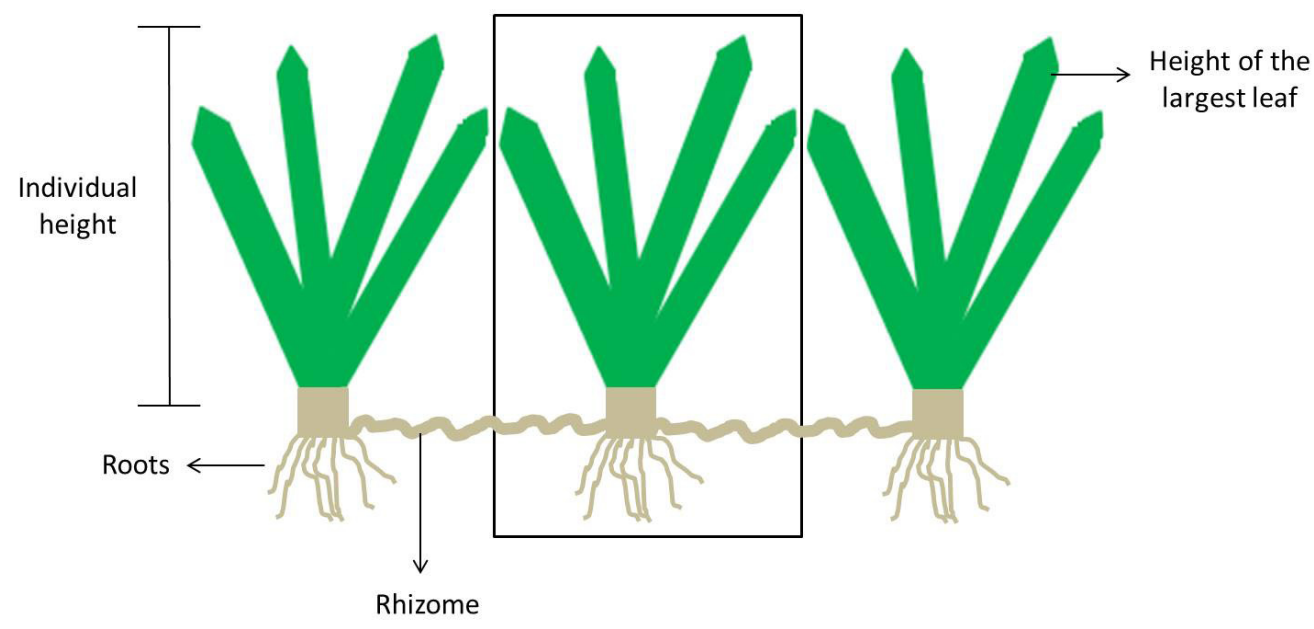

Figure 1. Scheme showing the emergent aquatic macrophyte Crinum americanum forming rosettes.

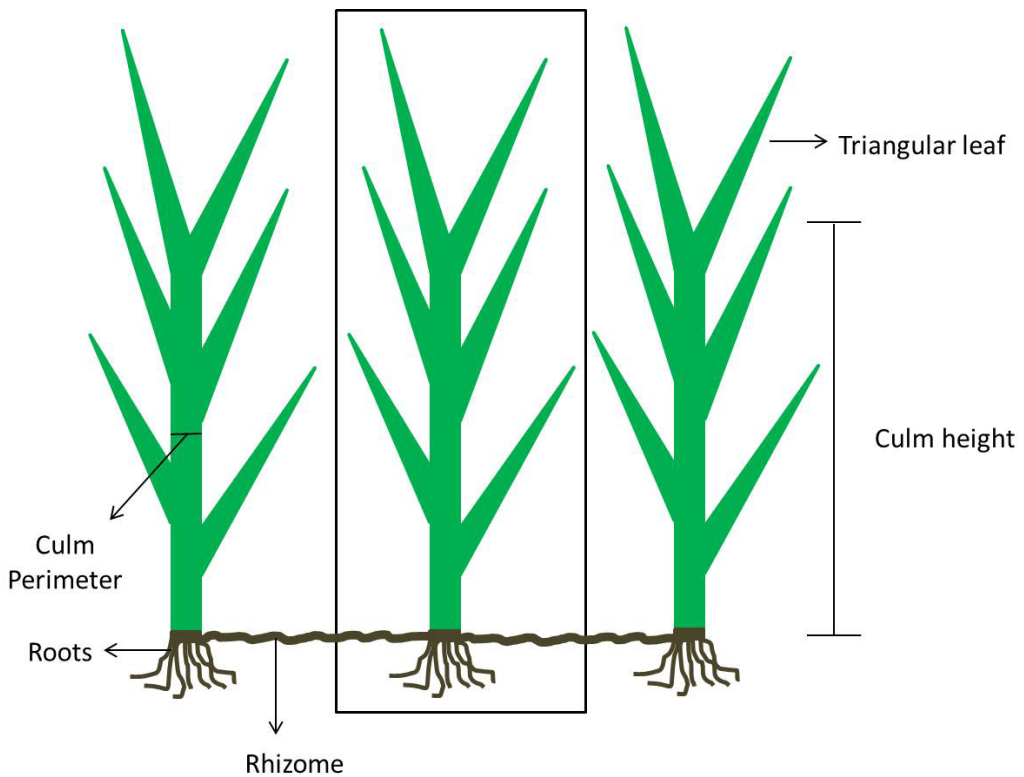

Figure 2. Scheme showing the emergent aquatic macrophyte $S$. alterniflora forming stems. 
these measures we obtained the rectangular and triangular areas using formulas of rectangle and isosceles triangle areas, and then added the two parts to obtain the leaf area. The sum of the area of all leaves of an individual was related to the individual's biomass. To calculate the aboveground area of $S$. alterniflora we considered its leaves as entirely triangular, and we obtained the width and the length of all leaves. In addition, for S. alterniflora we also determined the culm's area by obtaining the height and the perimeter measures of the culm's intermediate part. The sum of the area of all leaves and culm of an individual was related to the individual's biomass. The formulas used to calculate the aboveground area of $S$. alterniflora were those of the isosceles triangle area (leaves) and the cylinder area (culm).

The aboveground fraction of each individual of both species was dried in an oven (Adamo 310/150) at $60{ }^{\circ} \mathrm{C}$ until constant weight and then weighed on a balance (Ação Científica Mark 330 Class II) to obtain the corresponding biomass.

We tested the relationships between the individual area vs. biomass, and the individual height vs. biomass by using the GraphPad Prism
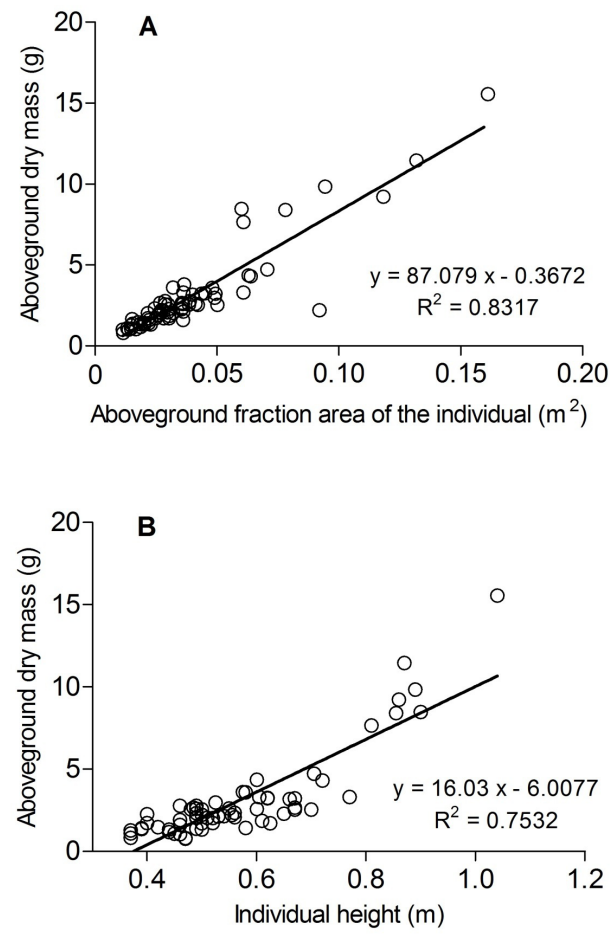

Figure 3. Simple linear regression between the individual aboveground area and aboveground dry mass (A), simple linear regression between the individual height and aboveground dry mass (B) of Crinum americanum, and linear equation and coefficient of determination $\left(\mathrm{R}^{2}\right)$.
5.0 software (GraphPad Software, 2007) with a simple linear regression equation between:

(1 A) Individual aboveground area and dry mass of $C$. americanum;

(1 B) Individual height and dry mass of C. americanum;

(2 A) Individual aboveground area and dry mass of S. alterniflora;

(2 B) Individual height and dry mass of S. alterniflora.

We found a significant coefficient of determination for all the models $(p<0.0001)$.

(1 A) Equation 1: C. americanum aboveground $\mathrm{DM}=87.079 *$ individual area $-0.3672\left(\mathrm{R}^{2}=0.8329\right)$ (Figure 3A).

(1 B) Equation 2: C. americanum aboveground $\mathrm{DM}=16.03 *$ individual height -6.0077 $\left(\mathrm{R}^{2}=0.7532\right)$ (Figure 3B).

(2 A) Equation 3: S. alterniflora aboveground $\mathrm{DM}=180.6353 *$ individual area -0.06458 $\left(\mathrm{R}^{2}=0.8343\right)$ (Figure 4A).

(2 B) Equation 4: S. alterniflora aboveground $\mathrm{DM}=10.64 *$ individual height -0.5451 $\left(\mathrm{R}^{2}=0.8279\right)$ (Figure 4B).
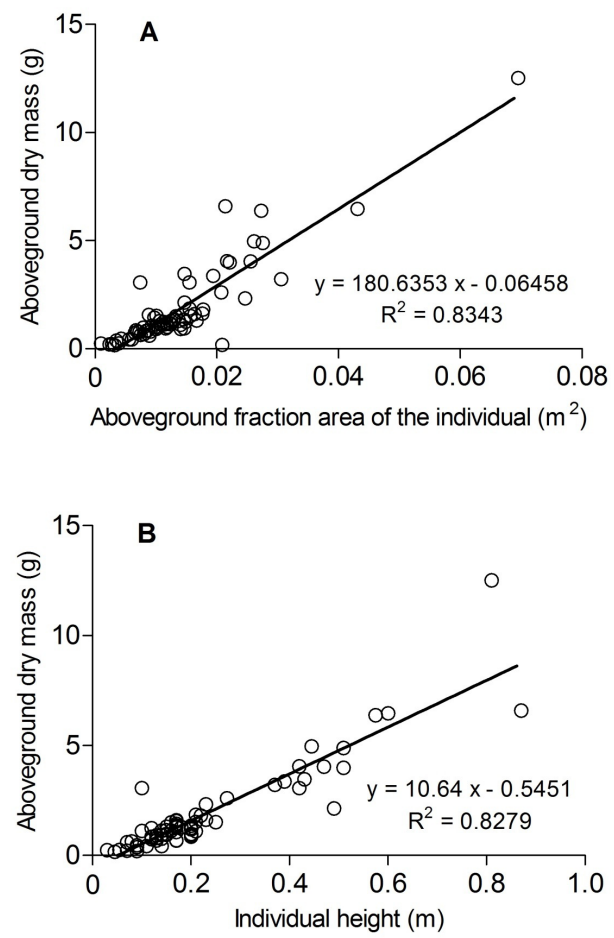

Figure 4. Simple linear regression between the individual aboveground area and aboveground dry mass (A), simple linear regression between individual height and aboveground dry mass (B) of Spartina alterniflora, and linear equation and coefficient of determination $\left(\mathrm{R}^{2}\right)$. 
Although all the equations have significant coefficient of determination, the time to obtain the value of the aboveground area is much greater than that for obtaining the individual height. Each individual of $C$. americanum has between 3 and 4 green leaves and each individual of $S$. alterniflora has between 2 and 3 green leaves. To estimate the species' biomass using the aboveground area (models $1 \mathrm{~A}$ and $2 \mathrm{~A}$ ), 9 to 12 measurements are required for each individual of $C$. americanum and 7 to 11 measurements for each individual of S. alterniflora. This amount is reduced to 1 measurement per individual when the individual height is used as a morphological measurement to estimate their biomass (models $1 \mathrm{~B}$ and $2 \mathrm{~B}$ ). For example, to estimate the biomass of a total of 10 C. americanum individuals and 10 S. alterniflora individuals with 4 leaves each, 120 morphological measurements are necessary for $C$. americanum and 110 for S. alterniflora if models $1 \mathrm{~A}$ and $2 \mathrm{~A}$, respectively, are adopted and only 10 measurements to 10 individuals if models $1 \mathrm{~B}$ and $2 \mathrm{~B}$ are used. Therefore, the sampling time and the number of measurements of morphological data are reduced by about $90 \%$ for each species using the individual height to estimate the biomass.

The non-destructive models developed in this study showed significant adjustment, indicating that the chosen morphological variables are good attributes to estimate the aboveground biomass of $C$. americanum and S. alterniflora. However, considering the adjustment of the tested models and the consumed time, the use of only the individual height showed good relation to the biomass of these two emergent long leaf species. It is also possible to test which morphological variables can be used to estimate the biomass of macrophytes with other leaf shapes.

Therefore, we recommend that previously to the development of macrophyte growth assessments, several morphological measurements be used so the simpler one can be chosen. Thus, this method allows us to develop an experimental design with more replications and treatments, obtain consistent results and reduce the working time and cost.

\section{Acknowledgements}

We thank Carlos Fernando Sanches and Amarílis Brandão de Paiva for their assistance in the field and laboratory work.

\section{References}

ARMSTRONG, N., PLANAS, D. and PREPAS, E. Potential for estimating macrophyte surface area from biomass. Aquatic Botany, 2003, 75(2), 173-179. http://dx.doi.org/10.1016/S0304-3770(02)00169-9.

BYRD, K.B., O’CONNELL, J.B., TOMMASO, S.D. and KELLY, M. Evaluation of sensor types and environmental controls on mapping biomass of coastal marsh emergent vegetation. Remote Sensing of Environment, 2014, 149, 166-180. http://dx.doi. org/10.1016/j.rse.2014.04.003.

CHAMBERS, P.A. and PREPAS, E.E. Competition and coexistence in submerged aquatic plant communities: the effects of species interactions versus abiotic factors. Freshwater Biology, 1990, 23(3), 541-550. http://dx.doi.org/10.1111/j.1365-2427.1990. tb00293.x.

DAI, T. and WIEGERT, R.G. Ramet population dynamics and net aerial primary productivity of Spartina alterniflora. Ecology, 1996, 77(1), 276-288. http://dx.doi.org/10.2307/2265677.

GOLZARIAN, M.R., FRICK, R.A., RAJENDRAN, K., BERGER, B., ROY, S., TESTER, M. and LUN, D.S. Accurate inference of shoot biomass from highthroughput images of cereal plants. Plant Methods, 2011, 7(1), 1-11. PMid:21284859. http://dx.doi. org/10.1186/1746-4811-7-2.

GOURAUD, C., GIROUX, J.F., MESLÉARD, F. and DESNOUHES, L. Non-destructive sampling of Schoenoplectus maritimus in southern France. Wetlands, 2008, 28(2), 228-232. http://dx.doi. org/10.1672/07-85.1.

GRAPHPAD SOFTWARE. Prism (Data Analysis Software System): version 5. [Serial number: GPW5066646-RCG7389]. 2007.

KIM, J.Y., IM, R.Y., DO, Y., KIM, G.Y. and JOO, G.J. Above-ground biomass estimation of tuberous bulrush (Bolboschoenus planiculmis) in mudflats using remotely sensed multispectral image. Ocean Science Journal, 2016, 51(1), 151-158. http://dx.doi. org/10.1007/s12601-016-0013-0.

LAUCK, M. and BENSCOTER, B. Non-destructive estimation of aboveground biomass in sawgrass communities of the Florida Everglades. Wetlands, 2015, 35(1), 207-210. http://dx.doi.org/10.1007/ s13157-014-0596-0.

LONG, B.G., SKEWES, T.D. and POINER, I.R. An efficient method for estimating seagrass biomass. Aquatic Botany, 1994, 47(3-4), 277-291. http:// dx.doi.org/10.1016/0304-3770(94)90058-2.

RIOS, G.F.A., RIOS, R.A., OLIVEIRA, G.S., RIBEIRO, F.C. and CARVALHO, L.G. Dispositivos associados à câmera digital comum para mensuração de área foliar de plantas no campo. In Anais do XLIII Congresso Brasileiro de Engenharia Agrícola. Campo Grande, 2014. 
SILVA, T.S.F., COSTA, M.P.F. and MELACK, J.M. Assessment of two biomass estimation methods for aquatic vegetation growing on the Amazon Floodplain. Aquatic Botany, 2010, 92(3), 161-167. http://dx.doi.org/10.1016/j.aquabot.2009.10.015.

THOMAZ, S.M. and ESTEVES, F.A. Comunidade de macrófitas aquáticas. In F.A. ESTEVES, ed. Fundamentos de limnologia. 3. ed. Rio de Janeiro: Interciência, 2011, pp. 461-518.
THOMAZ, S.M., BINI, L.M. and PAGIORO, T.A. Métodos em limnologia: macrófitas aquáticas. In C.E.M. BICUDO and D.C. BICUDO, eds. Amostragem em Limnologia. São Carlos: RiMa, 2004, $371 \mathrm{p}$.

Received: 09 September 2016 Accepted: 13 December 2016 